\title{
Temporal and spatial variation in adult and juvenile mobile fauna associated with natural and artificial coastal habitats
}

\author{
Alice E. Hall ${ }^{1}\left[\right.$ : Roger J. H. Herbert ${ }^{1} \cdot$ Richard Stafford $^{1}$
}

Received: 25 June 2020 / Accepted: 4 January 2021 / Published online: 25 January 2021

(c) The Author(s) 2021

\begin{abstract}
Coastal habitats are important for commercially exploited and protected species of fish and larger mobile invertebrates. The addition of artificial structures within the marine environment has the potential to alter the connectivity between habitats and to affect metapopulations of a region. Baited remote underwater videos (BRUV) were used to investigate the spatial and seasonal variation in abundance of adult and juvenile mobile species associated with subtidal natural and artificial habitats within Poole Bay on the south coast of England in 2019. Metrics included the relative maximum abundance (MaxN), number of species seen (S), assemblage structure and size range of fish. Higher values of MaxN and $\mathrm{S}$ were recorded on artificial structures in the spring and early summer; however, this pattern was reversed by mid-summer and early autumn when more fish were recorded on the natural reefs. Yet overall differences in MaxN and S between habitats were not significant. Differences in assemblage composition between habitats varied monthly, but this was mostly driven by particular sites. Although most fish observed were juveniles, there were some seasonal differences in the size of fish using natural and artificial sites, especially bib (Trisopterus luscus), black bream (Spondyliosoma cantharus), bass (Dicentrarchus labrax) and pollack (Pollachius pollachius). The artificial habitats in this region appeared to be important in certain months, so temporal studies of this type need to be incorporated within surveys, particularly those in proximity to protected areas.
\end{abstract}

\section{Introduction}

Coastal inshore habitats support a large variety of mobile marine fauna including commercial and protected species. In this study, habitat refers to an environment defined by specific abiotic and biotic factors, in which the species lives at any stage of its biological cycle (Habitats Directive, Council Directive 92/43/EEC). These habitats have been severely degraded through anthropogenic impacts such as fishing, coastal development, dredging and pollution, resulting in

Responsible Editor: K. D. Clements.

Reviewed by S. Elliott, V. Komyakova and an undisclosed expert.

Supplementary Information The online version contains supplementary material available at https://doi.org/10.1007/s0022 7-021-03823-0.

Alice E. Hall

ahall@bournemouth.ac.uk

1 Department of Life and Environmental Sciences, Faculty of Science and Technology, Bournemouth University, Poole, UK habitat loss and habitat fragmentation (Airoldi and Beck 2007; Aguilera 2018). Most fish spend at least part of their life within coastal regions and many species migrate over large distances, using these habitats as stepping stones for foraging and shelter (Vega Fernández et al. 2008). Coastal habitats often provide a key nursery ground, providing suitable food and a refuge for different life history stages (Beck et al. 2001; Gillanders et al. 2003; Dufour et al. 2009; Kopp et al. 2013; Seitz et al. 2014; Elliott et al. 2017).

The increasing numbers of artificial structures can (a) create physical barriers to movement, (b) introduce new materials that assist movement across a landscape and/or (c) alter trophic connectivity which in turn impact the genetic diversity and size of populations, the distribution of species and assemblage structure and ecological functioning of a population (Bishop et al. 2017). They also have the potential to become ecological traps as organisms may choose to settle out in poor quality habitat (Schlaepfer et al. 2002; Hale and Swearer 2016). Therefore, artificial structures could have an influence on the distribution of coastal mobile fauna, such as predatory fish species, by altering connectivity between isolated habitats and trophic relationships. 
Early work on the mobile fauna associated with subtidal artificial structures focussed on artificial reefs (reviewed by Baine 2001) and more recent studies have considered the impact of renewable energy installations (Wilhelmsson et al. 2006; Reubens et al. 2013; Krone et al. 2013; Langhamer et al. 2016; Bender et al. 2020; Glarou et al. 2020; Sheehan et al. 2020) and decommissioned oil rigs (Claisse et al. 2014, 2015). Yet work on other types of artificial structures in temperate regions, such as pipeline infrastructure and subtidal coastal defences, is lacking. This is particularly important in close proximity to protected areas where the connectivity between isolated habitats is important to understand.

Comparative studies on natural versus artificial reefs vary with some reporting similar assemblages of fish on natural and artificial reefs (Randall 1963; Bohnsack and Sutherland 1985; Bohnsack 1989), while others have found distinct assemblages on artificial reefs (Hackradt et al. 2011; Folpp et al. 2013) with species-specific recruitment occurring (Komyakova and Swearer 2019). Higher densities of fish have been recorded on artificial reefs (Bohnsack 1989; Folpp et al. 2013), whereas greater species richness and abundance has been measured on natural reefs (Carr and Hixon 1997; Hackradt et al. 2011). A recent meta-analysis found that across 39 relevant studies, artificial reefs supported comparable levels of fish density, species richness and diversity to natural reefs (Paxton et al. 2020). In some cases, artificial reefs have been shown to support increased number of fish (Bohnsack 1989; Pickering and Whitmarsh 1997). However, it is uncertain whether this is due to attraction and/or production. In regions where suitable natural habitat is available the creation of artificial reefs may negatively affect the fitness of fish populations due to provision of poor quality habitat and lack of habitat diversity (Komyakova and Swearer 2019). Fish are known to aggregate around changes in topography (Randall 1963), either in the form of natural reefs or artificial structures. Increased fish species richness and abundance has been shown to be related to greater habitat diversity (Hackradt et al. 2011; Davis and Smith 2017), and fish species richness and abundance was found to be higher on reef habitats than surrounding sediment (Schultz et al. 2012; Folpp et al. 2013; Davis and Smith 2017).

The quality of the nursery habitat and feeding areas can determine the number of individuals that will contribute to the adult population, therefore identifying juvenile fish habitat is crucial for conservation (Gillanders et al. 2003), and this may vary seasonally (Komyakova and Swearer 2019). Harbours and marinas have been shown to create nursery habitats for juvenile bass in the north-western Mediterranean (Dufour et al. 2009), and breakwaters have been found to support higher densities of sea bream than natural habitats on the Catalan coast of France (Pastor et al. 2013). Although some studies have focused on particular species (Komyakova and Swearer 2019), the influence of seasonal variation in populations and assemblages on both inshore natural and artificial habitats has not been well researched. For example, it is possible that species might utilise resources of both habitat types at different life history stages.

Although telemetry and genetic analysis are increasingly applied to establish habitat connectivity, these techniques remain expensive and not yet widely used in all coastal areas. An indirect approach to infer movement and connectivity is through the investigation of changes in abundance and size classes in spatially separated habitats (Gillanders et al. 2003). Underwater camera techniques allow data acquisition in a non-destructive manner, such as baited remote underwater video (BRUV), remotely operated vehicles (ROV) and diver-based surveys (Schramm et al. 2020). BRUV is used around the world in a variety of habitats including coral reefs, rocky reefs and seagrass. It is useful in protected areas due to its non-extractive nature and in sites that may be hazardous or inaccessible to divers, including artificial structures (Cappo et al. 2004; Malcolm et al. 2007; Dorman et al. 2012; Unsworth et al. 2014; Schmid et al. 2017; Whitmarsh et al. 2017). Stereo BRUV has been developed to allow accurate measurements of fish species to determine the proportion of adults and juveniles within a particular area (Unsworth et al. 2014; Griffin et al. 2016).

The aims of this study were to investigate differences in the spatial and temporal structure of mobile reef assemblages in natural and artificial habitat within Poole Bay using the following hypotheses:

There will be a significantly higher maximum number of individuals observed in any one frame (MaxN) and greater number of species (S) recorded on natural sites in comparison with artificial sites due to increased habitat diversity.

The assemblage structure will be significantly different between natural and artificial sites due to habitat variability, and there will be a greater variety of species in the warmer summer months due to inshore migration and recruitment.

The size and number of adult and juvenile fish associated with natural and artificial habitats will vary throughout the months due to recruitment and growth.

\section{Methods}

\section{Study site}

Poole Bay is predominantly sand with small isolated subtidal rocky outcrops of sandstone reefs and mixed sediment. Within the bay there are several artificial structures including piers, outfall pipelines, artificial reefs and subtidal breakwaters. There are two marine protected 
areas/marine conservation zones (MCZ) within Poole Bay (Fig. 1): Poole Rocks MCZ is located to the east of Poole Harbour entrance, and Studland Bay MCZ is located to the south-west of Poole Bay. A variety of species of fish including bass (Dicentrarchus labrax), black bream (Spondyliosoma cantharus) and pollack (Pollachius pollachius) are exploited using nets, trawls and by anglers on chartered vessels. Pots for lobster (Homarus gammarus) and brown crab (Cancer pagurus) are set around the reefs and some structures (SIFCA 2020).

Three undisturbed natural patch reef habitats (Inner Poole Patch, Durley Rocks and Outer Poole Patch) (Fig. 1, Table 1) and three accessible artificial habitats were studied: a subtidal limestone breakwater (known as the Training Bank, as it "trains" water out of Poole Harbour on an ebb tide) constructed in 1924, a disused outfall pipeline

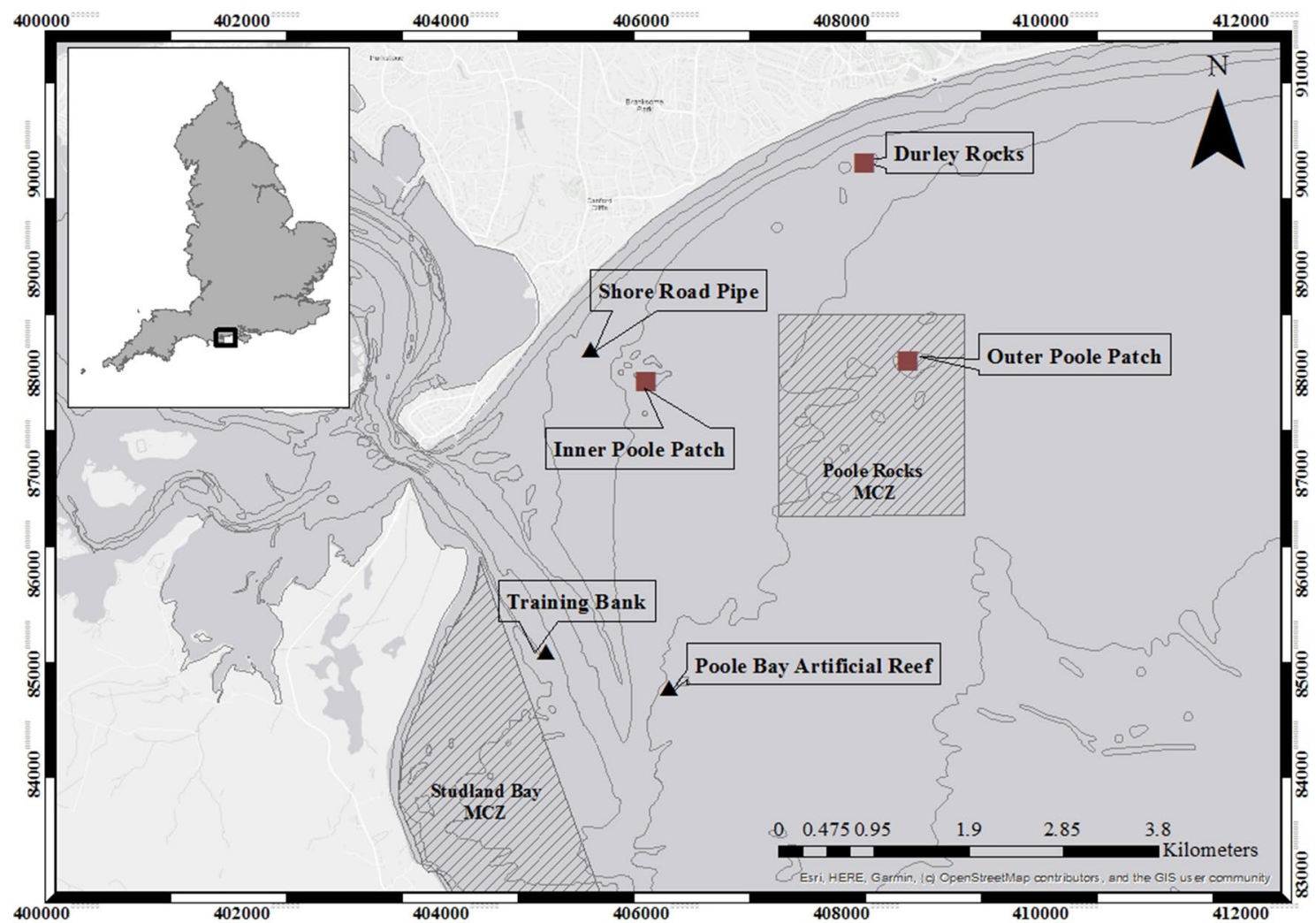

Fig. 1 Location of survey sites within Poole Bay, UK. Natural sites indicated with brown square-Inner Poole Patch, Outer Poole Patch and Durley Rocks. Artificial sites indicated by black triangle_-Training Bank, Shore road pipe and Poole Bay Artificial Reef

Table 1 Habitat, site, coordinates, depth and habitat area for all six sites

\begin{tabular}{|c|c|c|c|c|}
\hline Habitat & Site & Coordinates (WGS84) & $\begin{array}{l}\text { Depth: chart datum } \\
\text { (m) }\end{array}$ & Total habitat size (patch size) \\
\hline Artificial & Training Bank & $\begin{array}{l}5039.873^{\prime} \mathrm{N} \\
00155.943^{\prime} \mathrm{W}\end{array}$ & $3-4 \mathrm{~m}$ & $0.0096 \mathrm{~km}^{2}$ \\
\hline Artificial & Shore Road Pipe & $5041.510^{\prime} \mathrm{N} 00155.451^{\prime} \mathrm{W}$ & $3-5 \mathrm{~m}$ & $0.005 \mathrm{~km}^{2}$ \\
\hline Artificial & Poole Bay Artificial Reef & $\begin{array}{l}5039.725^{\prime} \mathrm{N} \\
00154.853^{\prime} \mathrm{W}\end{array}$ & $9-10 \mathrm{~m}$ & $0.001225 \mathrm{~km}^{2}$ \\
\hline Natural & Inner Poole Patch & $\begin{array}{l}5041.371^{\prime} \mathrm{N} \\
00155.058^{\prime} \mathrm{W}\end{array}$ & $4-7 \mathrm{~m}$ & $0.2 \mathrm{~km}^{2}\left(0.05 \mathrm{~km}^{2}\right)$ \\
\hline Natural & Durley Rocks & $\begin{array}{l}5042.510^{\prime} \mathrm{N} \\
00153.128^{\prime} \mathrm{W}\end{array}$ & $5-9 \mathrm{~m}$ & $0.2 \mathrm{~km}^{2}\left(0.08 \mathrm{~km}^{2}\right)$ \\
\hline Natural & Outer Poole Patch & $\begin{array}{l}5041.443^{\prime} \mathrm{N} \\
00152.756^{\prime} \mathrm{W}\end{array}$ & $6-12 \mathrm{~m}$ & $0.5 \mathrm{~km}^{2}\left(0.15 \mathrm{~km}^{2}\right)$ \\
\hline
\end{tabular}


surrounded by rock armour built in 1890s (Shore Road Pipe) and a purpose built pulverised fuel ash concrete artificial reef constructed in 1989 [Poole Bay Artificial Reef (Collins et al. 1990)] (Fig S1). All six sites were located within a $10 \mathrm{~km}^{2}$ area with distance between sites ranging from 0.7 to 6 km (Fig. 1, Table 1).

\section{Methods}

Baited remote underwater video (BRUV) was used to characterise the mobile fauna (fish and larger invertebrates, e.g. crabs, lobsters, cuttlefish, squid, and whelks) of three natural and three artificial habitats within Poole Bay. Sampling was conducted using three mono BRUV units and one Stereo BRUV placed randomly on the sea bed within a site, $>300 \mathrm{~m}$ apart to prevent confounding issues of fish moving between sampling locations (Haggitt et al. 2014). Mono BRUV allows relative abundance and number of species seen to be estimated. Fish length measurements were made using stereo BRUVs, which enables determination of the proportion of adult and juvenile fish species present in each habitat (Unsworth et al. 2014). BRUV deployments of 30-min soak time were conducted from a boat at each of the six sites in April, May, June, July, August and September $2019(n=144)$. Soak time was determined by species accumulation curves produced in previous local research (Hall 2018). Four replicate videos were obtained at random (nonfixed) locations from each site during each month.

The mono BRUV units consisted of a single GoPro Hero 3 high-definition camera with underwater housing fixed to a weighted aluminium frame $\left(460 \mathrm{~mm}^{2}, 660 \mathrm{~mm}\right.$ tall; weight $11.5 \mathrm{~kg}$ ). The stereo BRUV unit consisted of two GoPro Hero 5 cameras mounted in SeaGIS (SeaGIS Ply Ltd 2020) underwater housings (Medium FOV). The stereo housings were separated by $500 \mathrm{~mm}$ and set at an angle of $5^{\circ}$ convergence, and the housings were fixed to a large weighted metal frame $(1 \mathrm{~m} \times 0.5 \mathrm{~m})$. The stereo BRUV units were calibrated prior to the surveys using the SeaGIS calibration cube and calibration software (CAL) (Harvey and Shortis 1998). For both mono and stereo BRUV, a plastic bait-arm (20 mm diameter) attached to the base of the frame extended horizontally for $1 \mathrm{~m}$ in front of the camera. Bait, which consisted of $100 \mathrm{~g}$ of freshly chopped and crushed mackerel, was retained in a plastic cage ( $5 \mathrm{~mm}$ mesh) at the end of the bait arm and was replaced for each deployment. A 5-min settlement period was allowed before the data recording starts to allow the sediment plume to diminish.

EventMeasure (SeaGIS Ply Ltd 2019) was used to collect data on relative abundance (MaxN) for species seen with $3 \mathrm{~m}$ visibility on each deployment. MaxN is the maximum number of individuals seen in any one frame during the 25-min video, which avoids repeat counts of individuals (Cappo et al. 2004). Number of species seen: the total number of species seen over $25 \mathrm{~min}$ (S) was also calculated for each video (Schramm et al. 2020). We chose to calculate MaxN and number of species seen as they are well known BRUV metrics in existing literature (Whitmarsh et al. 2017). EventMeasure (Stereo) software was used to collect 3D length measurements of fish captured on the stereo video footage. In order for a fish to be measured, it had to be visible in both the right and left camera field of view and orientated so the head and the tail are visible, and fork length measurements with RMS $>20$ were excluded (Harvey and Shortis 1998). Fish were classified into adult and juveniles based on size information obtained from FishBase (Froese and Pauly 2019).

\section{Statistical analysis}

A four factor generalised liner model (GLM) with quasiPoisson distribution was used to test for significant differences in both MaxN and number of species seen between 3 fixed factors: Month, Depth, Habitat (Natural/Artificial) and 1 random factor: Site (nested in Habitat; Natural: Inner Poole Patch, Durley Rocks, Outer Poole Patch, Artificial: Training Bank, Poole Bay Artificial Reef, Shore road pipeline). All models were tested for over-dispersion, collinearity and the deviance residuals were plotted and checked (Harrison et al. 2018). Quasi-Poisson distribution was used as the data were only slightly over dispersed and consisted of count data (Crawley 2012). Individual linear regressions were run against the MaxN data and depth and the number of species seen data and depth.

Individual PERMANOVAs were run to assess the difference in mobile assemblage (e.g. fish, crabs, lobsters, cuttlefish, squid) structure between (a) Habitat, (b) Site nested in Habitat and (c) Month using MaxN data (Anderson 2001). The data were square-root transformed prior to use, to avoid the weighting of common species over rare. A Bray-Curtis resemblance matrix was used with 9999 permutations and PERMANOVA run with unrestricted permutation of raw data. Significant results were followed by post hoc tests to explore which sites or months were significantly different. Canonical analysis of principal coordinates (CAP) was used to visualise variation between sites (Anderson and Willis 2003).

To investigate differences in fish size between natural and artificial habitats for the four most abundant species (i.e., bib, black bream, bass and pollack) $F$-tests and $T$-tests were run on the mean fish length data.

\section{Results}

Overall 3933 individuals of 39 species were recorded across all months and sites including 29 species of fish (Table S1). Natural habitats had higher numbers of goldsinny wrasse 
(Ctenolabrus rupestris), cuckoo wrasse (Labrus mixtus) and rock cook (Centrolabrus exoletus), whereas artificial habitats had higher abundances of sand eel (Ammodytes tobianus) and rays (Raja sp.). The sites with the highest number of species were Inner Poole Patch and Poole Bay Artificial Reef $(S=10)$ and the site with the greatest abundance of individuals was Poole Bay Artificial Reef (MaxN=150). The highest number of species were recorded in September $(S=10)$ and greatest maximum abundance (MaxN) was recorded in June $(\mathrm{MaxN}=150)$ at Poole Bay Artificial Reef. Observed water depth varied within and between sites (Fig. 2) with the natural sites showing greatest variability within site (Fig. 2).

\section{$\operatorname{MaxN}$}

There was a significant difference in mean MaxN between Month, Depth and Site, yet no significant difference in Habitat (Table 2, Fig. 3 and Fig. S2). Poole Bay Artificial Reef had a significantly greater MaxN than all other sites
$(P<0.001$, Fig. 3). Additionally, the Training Bank and Shore Road Pipe had lower mean MaxN than all other sites and there was no significant difference between the MaxN at the three natural sites (Fig. 3). Overall, June has the greatest mean MaxN across all months $(P<0.001$, Fig. 3).

\section{Number of species seen}

There was a significant difference in mean number of species seen between Month and Depth but no significant difference between Habitat or Site (Table 3, Fig. 4 and Fig. S3). The number of species seen was significantly lower in April and significantly higher in September (Fig. 4).

\section{Assemblage structure}

Significant differences in assemblage structure were found between Habitat, Site and Month (Table 4). Pairwise tests revealed significant differences between all artificial sites but no significant differences between any of the natural

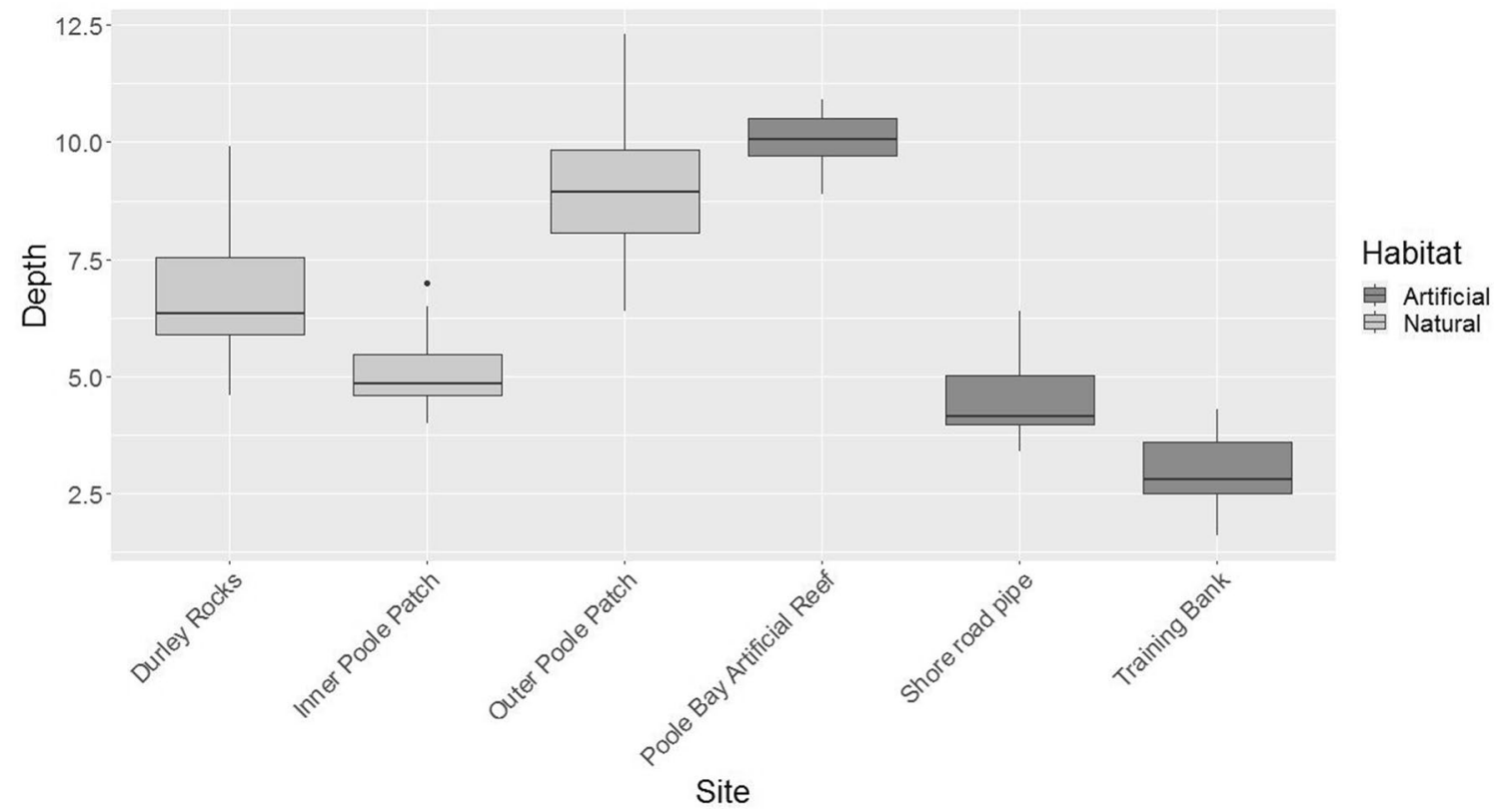

Fig. 2 Observed water depth $(\mathrm{m})$ variation for each Baited Remote Underwater Video (BRUV) deployment at each site between April-September 2019 within Poole Bay $( \pm$ SE, $n=24)$

Table 2 Generalised linear model results for MaxN data comparisons between month, depth, habitat and site nested in habitat for all 2019 samples

\begin{tabular}{llrllll}
\hline & df & Deviance & Resid. df & Resid. dev & $P$ & $\%$ Explained \\
\hline Month & 5 & 609.34 & 136 & 3620.36 & $0.0006^{* * *}$ & 13 \\
Depth & 1 & 504.81 & 142 & 4231.73 & $0.0001^{* * *}$ & 11 \\
Habitat & 1 & 2.04 & 141 & 4229.70 & $0.7869 \mathrm{NS}$ & 0.04 \\
Site(Habitat) & 4 & 561.84 & 132 & 3058.51 & $0.0005^{* * *}$ & 12 \\
\hline
\end{tabular}

NS not significant

$r^{2}=0.35(* * * P<0.001)$ 


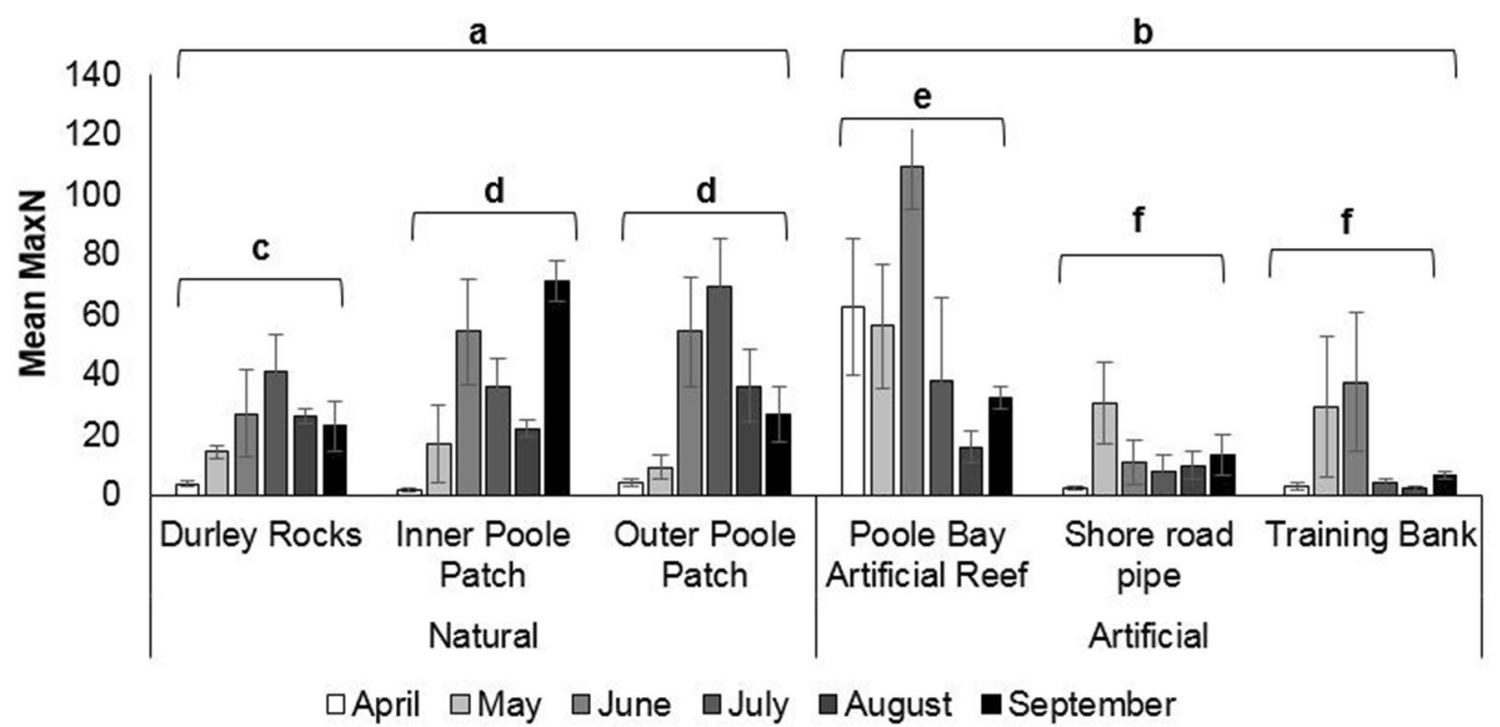

Fig. 3 Mean maximum abundance (MaxN) of mobile fauna observed during $25 \mathrm{~min}$ baited remote underwater video (BRUV) surveys conducted between April and September 2019, from six sites within Poole Bay (Replicate $n=24, \pm$ S.E.). Differences in letters represent significantly different groupings ( $\mathbf{a}, \mathbf{b}$ between habitats; $\mathbf{c}, \mathbf{d}$ between sites within natural habitats; $\mathbf{e}, \mathbf{f}$ between sites within artificial habitats)
Table 3 Generalised Linear Model (GLM) for number of species seen data comparisons between month, depth, habitat and site nested in habitat for all 2019 samples

\begin{tabular}{llclllc}
\hline & df & Deviance & Resid. df & Resid. dev & $P$ & $\%$ Explained \\
\hline Month & 5 & 24.20 & 136 & 142.25 & $0.0001^{* * *}$ & 14 \\
Depth & 1 & 7.62 & 142 & 168.17 & $0.005^{* *}$ & 4 \\
Habitat & 1 & 1.72 & 141 & 166.45 & $0.189 \mathrm{NS}$ & 1 \\
Site(Habitat) & 4 & 4.56 & 132 & 137.68 & $0.335 \mathrm{NS}$ & 3 \\
\hline
\end{tabular}

NS not significant

$r^{2}=0.250(* * P<0.005, * * * P<0.001)$

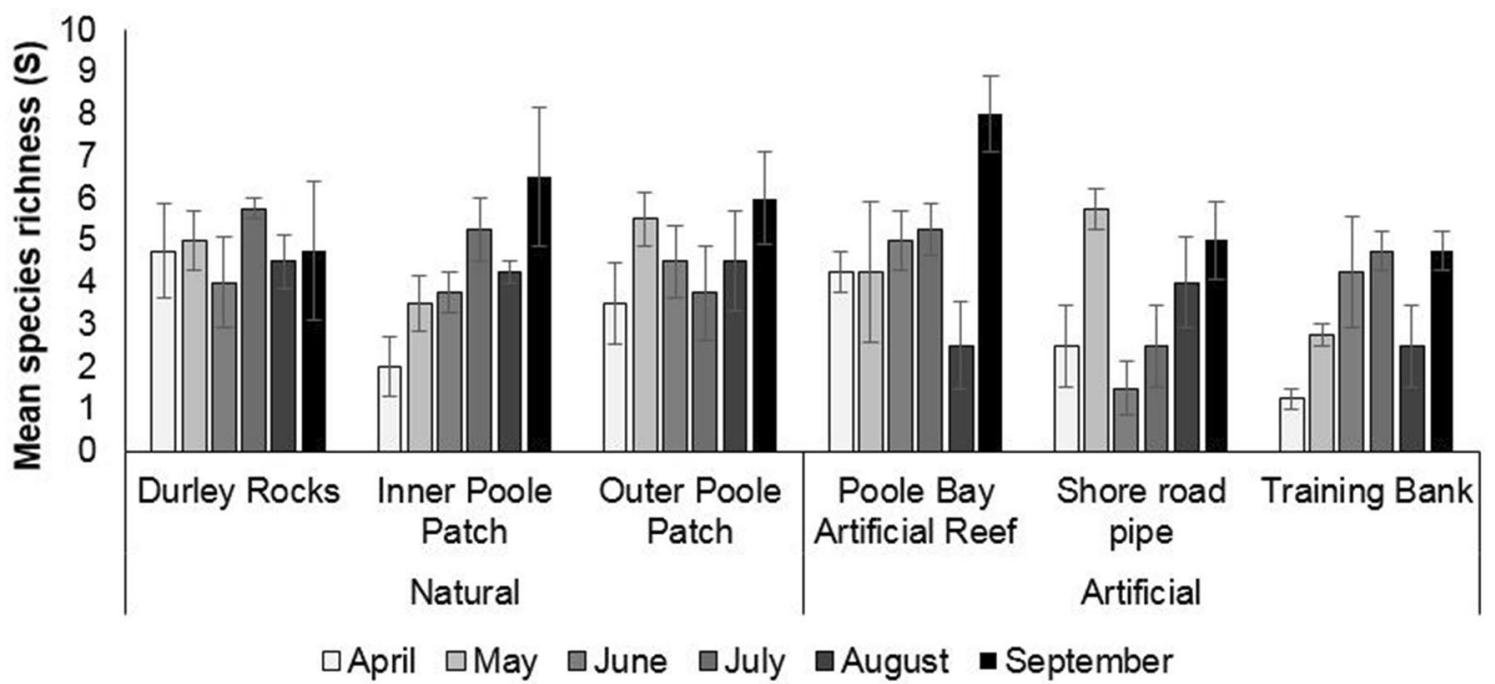

Fig. 4 Mean number of species seen (S) of mobile fauna observed during 25 min baited remote underwater video (BRUV) surveys conducted in April, May, June, July, August and September 2019 from artificial and natural sites within Poole Bay $(n=24, \pm$ S.E. $)$. There were no significant differences between habitats or site within habitats 
sites (Table S2). Pairwise tests also revealed significant differences between April-May, April-June, April-July, April-August, April-September, May-September and August-September (Table S2).

The CAP plot shows that four species contributed significantly to the variation between sites. Pollack were most common on the Training Bank, black bream on Shore Road Pipe, goldsinny wrasse on Durley Rocks and Inner Poole Patch. Bib were commonly found on most natural sites and also Poole Bay Artificial Reef (Fig. 5). In addition, Baillon's wrasse (Symphodus bailloni) were only recorded on two of

Table 4 Individual PERMANOVA results for tests between habitat, site and month on MaxN of mobile fauna collected from 2019 BRUV surveys within Poole Bay (number of permutations 9999)

\begin{tabular}{llllll}
\hline Source & df & SS & MS & Pseudo-F & $P$ (perm) \\
\hline Habitat & 1 & 14,767 & 14,767 & 7.5523 & 0.0002 \\
Site & 5 & 56,288 & 11,258 & 6.5794 & 0.0001 \\
Month & 5 & 31,773 & 6354.6 & 3.3645 & 0.0001 \\
\hline
\end{tabular}

the natural sites, Durley Rocks and Inner Poole Patch, and corkwing wrasse (Symphodus melops) were mainly recorded on the three natural sites.

\section{Fish length}

EventMeasure was used to measure 619 individual fish across thirteen species (Table S3). The four most abundant species measured were bib, bass, pollack and black bream and the majority of these were juveniles. Bib, bass and pollack were significantly larger on natural habitats than artificial habitats, but with no significant difference in variance of size (Bib $T_{360}=-4.58, P=<0.001$; Bass $T_{39}=-7.72$, $P<0.001$; Pollack $T_{30}=-2.93, P<0.01 ; F$-test $P>0.05$ in all cases). Black bream were larger, but also with a significantly higher variance on artificial compared to natural habitats $[F=0.144, P<0.001: T$ test (assuming un-equal variances) $\left.\left.T_{56}=7.41, p<0.001\right)\right]$.

The mean length of bib was greater on natural sites across all three seasons (Fig. 6a). Only one black bream adult was recorded on a natural site in summer, with the remainder

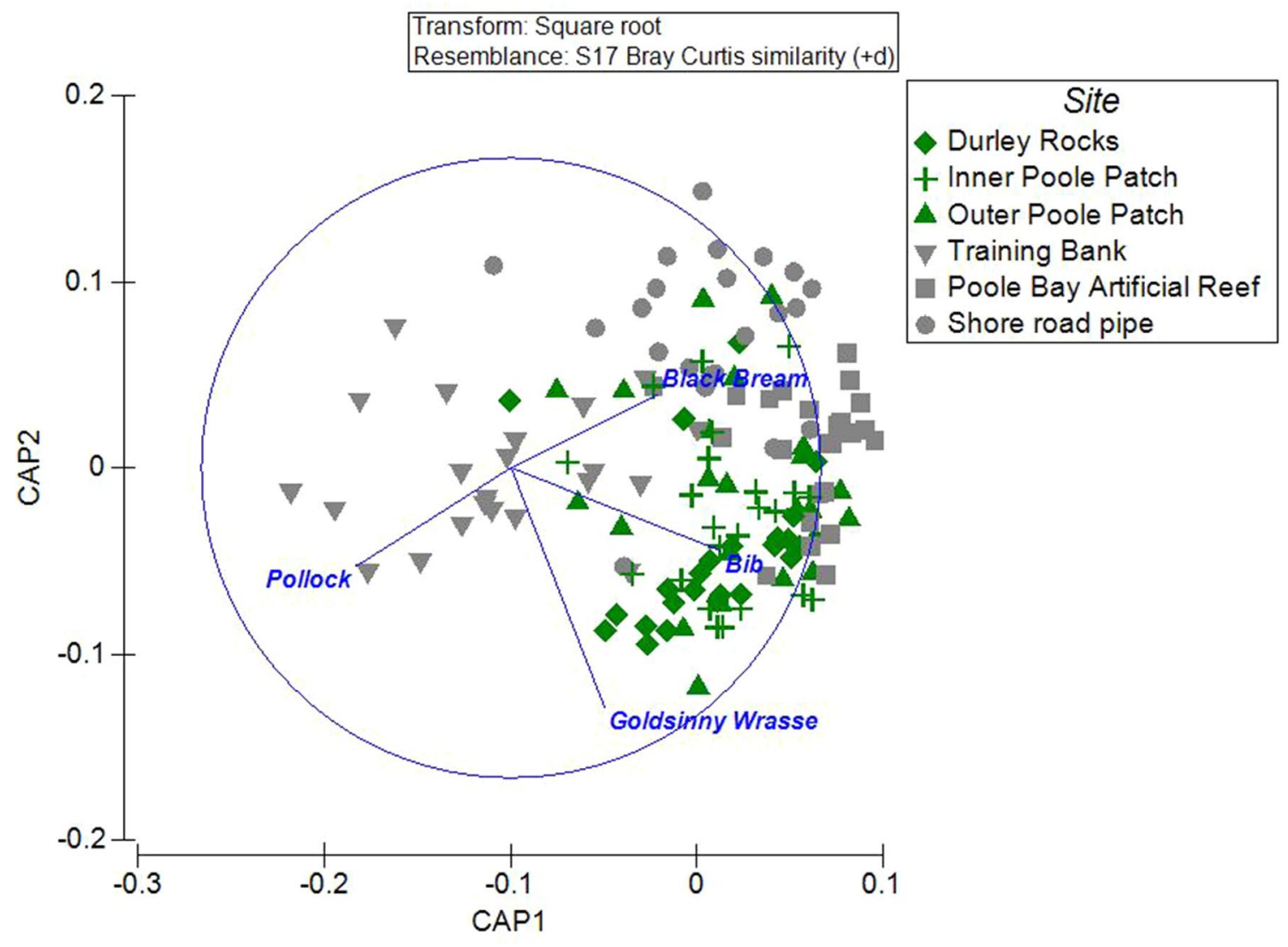

Fig. 5 Canonical analysis of principal coordinates (CAP) plot for site-green symbols indicate natural habitats (Durley Rocks, Inner Poole Patch and Outer Poole Patch), and grey symbols indicate artificial habitat (Training Bank, Poole Bay Artificial reef and Shore road pipe). Spearman's Rank correlation vectors $(>5)$ overlaid in blue. Discriminant analysis is based on 10 PCO axes accounting for $52.1 \%$ variability within the data 
being juveniles; the smallest fish were recorded solely on natural habitats $(60-90 \mathrm{~mm})$, and the medium-sized bream $(150-210 \mathrm{~mm})$ were most abundant on the artificial habitats (Fig. 6b). The largest adult bass were recorded in autumn on the natural sites; juvenile bass were only recorded on artificial sites in summer and autumn. The mean length of pollack was larger in spring and summer on natural sites yet greater on artificial sites in autumn and all pollack measured were juvenile size (Fig. 6d).

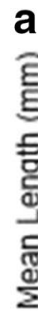
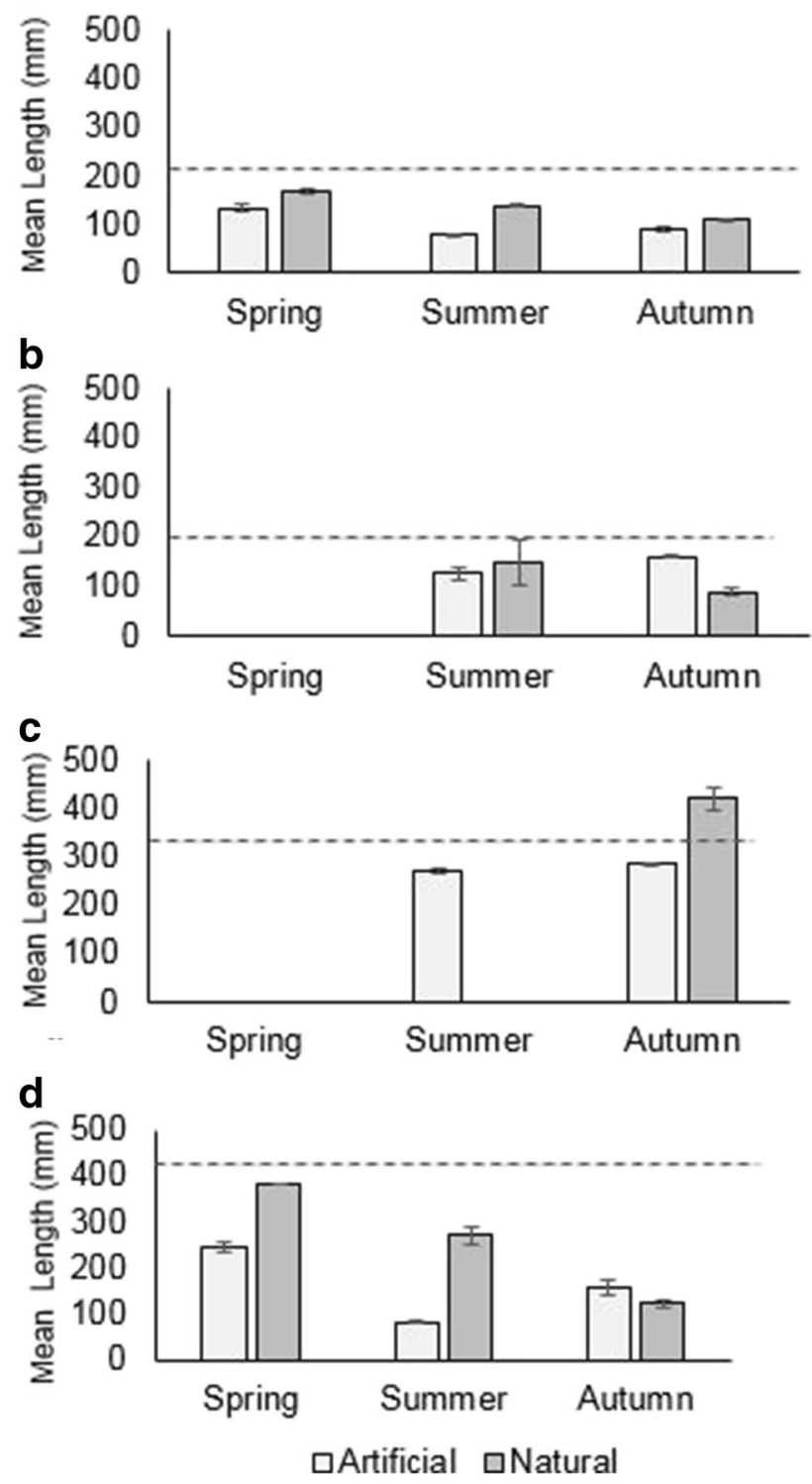

Fig. 6 Mean fish length $(\mathrm{mm})$ on natural and artificial sites of a Bib (artificial $n=108$, natural $n=254$ ) b Black Bream (artificial $n=30$, natural $n=42$ ) c Bass (artificial $n=37$, natural $n=4$ ) d Pollack (artificial $n=25$, natural $n=7$ ) in Spring (April/May), Summer (June/July) and Autumn (August/September) 2019 ( \pm S.E.). Red line indicated adult size according to Fish base-Bib $=216 \mathrm{~mm}$, Black bream $=197 \mathrm{~mm}$, Bass $=323 \mathrm{~mm}$, Pollack $=410 \mathrm{~mm}$ (Froese and Pauly 2019)

\section{Discussion}

Artificial structures supported higher abundances in the spring and early summer. This pattern reversed by midsummer and early autumn when more fish were recorded on the natural reefs. Yet overall seasonal differences in abundance and number of species seen between habitats were not significant. The maximum abundance of individuals peaked in the summer and the number of species seen and maximum abundance increased with depth. A large proportion of fish recorded on all sites were smaller fish and assumed to be juveniles; overall bib, bass and pollack were larger on natural sites, whereas black bream were larger on the artificial sites.

BRUV was a useful tool to detect differences in the community structure of mobile fauna in this study and coupled with Stereo cameras systems it allowed a high level of accuracy in length measurements (Dunlop et al. 2015). Although BRUV has been criticised for recording relative abundance (MaxN) and not density, it has shown to be a cost-effective non-destructive method which overcomes problems with diver-based fish avoidance (Schramm et al. 2020). MaxN was used rather than other metrics (Whitmarsh et al. 2017) such as "meancount" (Bacheler and Shertzer 2015) as this has shown to over inflate zero observations (Campbell et al. 2015). MaxN accounts for both fauna attracted to the bait and the presence of the camera frame, alongside species which are just passing through the field of view. The majority of fish in this study were not observed to be actively feeding on the bait. Variation in bait plume dispersal at each site could influence species abundance; however this is difficult to control (Harvey et al. 2007). BRUV can also favour certain species such as predators and overlook smaller cryptic species (Schramm et al. 2020). Another disadvantage of BRUV is that it is stationary and the field of view is dependent on where it is deployed meaning the wider habitat diversity is unknown. However, the BRUVs recorded more species and individuals compared to diver and remotely operated vehicle surveys (Schramm et al. 2020).

\section{Differences between habitats and sites}

Habitat type was not found to be a significant factor in the variation in communities within Poole Bay. This contradicts previous studies that have found higher abundances on artificial reefs in comparison with natural habitats (Ambrose and Swarbrick 1989; Bohnsack 1989; Folpp et al. 2020). Both habitat complexity and habitat diversity are known to affect the community structure of fish populations (Nanami and Nishihira 2003; Messmer et al. 2011; 
Loke et al. 2015). Although habitat complexity was not measured directly in this study, we did observe clear differences between sites. Evidence has shown that reef fish choose holes that are closest to their body size (Randall 1963 ) and that the size of demersal fish is dependent on the amount of substrate complexity (Elliott et al. 2016). Therefore, if a variety of habitat complexities are available the site will have the potential to support a greater number of individuals and species of varying life stages. Certain sites were more structurally complex than others, for example the natural reefs consisted of multiple-sized boulders and rocks with overhangs and deep crevices, whereas Shore Road Pipe and the Training Bank were very linear and consisted of straight edges and boulders of uniform size. The Poole Bay Artificial Reef was designed specifically for marine life and contains a variety of habitat types created by the informed positioning of concrete blocks (Mallinson et al. 1999; Jensen et al. 2000). This increased habitat complexity is possibly linked to higher abundances of mobile fauna found on the Poole Bay Artificial Reef as determined in previous research (Hunter and Sayer 2009); however in some cases increased habitat complexity has been shown to have a negative ecological impact through increases in density-dependant mortality of juvenile fish (Johnson 2006).

Previous studies have found that community similarity was more stable on artificial reefs when compared to natural reefs (Bohnsack et al. 1994). This study found there was greater similarity in assemblage composition on natural reefs than artificial reefs, reinforcing the theory of increased community stability (Connell and Statyer 1977). Assemblages on natural and artificial reefs have been shown to have varying degrees of similarity depending on the season (Burt et al. 2009), and this finding was also observed in this study. This variation in assemblage composition is often tied to recruitment in the summer months and migration in the spring and winter months (Bohnsack et al. 1994; Burt et al. 2009).

\section{Seasonal changes}

There were clear differences recorded between the months across all sites. The highest overall number of species seen was recorded in September and the lowest number of species seen in April, which coincides with seasonal fluctuations in water temperature (Hiscock et al. 2004; Perry et al. 2005). Water temperature is known to influence species distributions (Hiscock et al. 2004; Perry et al. 2005) and is an important factor in both fish and crustacean metabolism (Stoner 2004; Moland et al. 2011). Seasonal variation in water temperature has shown to be correlated with fish abundance (Sanders et al. 1985), European lobster abundance (Moland et al. 2011) and whiting distribution (Zheng et al. 2002). This study found that abundance of mobile fauna increased between April and June after which it declined, which could be linked to food availability (Temming et al. 2004; Dalpadado et al. 2009; Reubens et al. 2014). Inner Poole Patch and Poole Bay Artificial Reef had a significantly higher abundance in September due to large shoals of juvenile black bream at both sites. Increased abundance of juveniles in September relates to recruitment timings (Bohnsack et al. 1994; Burt et al. 2009) and has been recorded at other sites nearby (Herbert et al. 2017). This emphasises the importance of temporal monitoring of both abundance and the number of species seen to detect these trends.

\section{Depth}

As artificial structures are constructed at different depths, it is important to understand how depth variation can influence the mobile assemblages in coastal habitats. There was a significant increase in the abundance and number of species seen of mobile fauna with increased depth, which supports previous studies (Brook 2002; Anderson and Millar 2004). Increased depth and reduced light levels can alter the benthic flora, shifting from algal dominated assemblages in shallow regions to bryozoan dominated assemblages in deeper water (Ponti et al. 2015; Herbert et al. 2017). The change in benthic flora can also influence the distribution of mobile predators and scavengers. The maximum depth varied between 3 and $12 \mathrm{~m}$, which is relatively shallow in comparison with previous studies (Humphries et al. 2016). The largest changes in topography were seen at Outer Poole Patch where the highest number of species was recorded, supporting the idea that increased habitat complexity at multiple scales can yield a higher number of species (Hunter and Sayer 2009). The two deeper sites, Outer Poole Patch and Poole Bay Artificial Reef, had four species which were unique to these sites: European lobster (Homarus gammarus), lesser spotted catshark (Scyliorhinus canicula), john dory (Zeus faber) and the small eyed ray (Raja microocellata). These four species are all known to inhabit deeper waters (Dunn 2001; Moland et al. 2011; Wearmouth et al. 2013; Humphries et al. 2016) suggesting that depth is the determining factor in their presence at these two sites. These two sites also had the largest abundances of bib which could be related to the increased site depth providing more protection from fishing pressures and predation (Jennings et al. 2001).

\section{Fish size}

The majority of the fish measured on both habitat types were juveniles, supporting other work demonstrating the importance of coastal habitats for juvenile fish (Beck et al. 2001; Stål et al. 2008; Kopp et al. 2013). These included bass, black bream and pollack, which are commercially fished, thus larger individuals may have been absent due to fishing 
mortality. In situ length measurement data is often lacking in studies due to the difficulties in obtaining it; however through the use of stereo BRUV this was possible.

The shallower artificial sites were typically colonised by tall macroalgae which provided additional refuge for smallto medium-sized juvenile species, whereas the natural sites were colonised in shorter turf and foliose algae that provided refuge for the smallest individuals. The habitat to body size ratio is an important factor as fishes are normally found in greatest abundances at sites with shelters the same size as their bodies (Hixon and Beets 1989). This study suggests that both artificial and natural sites could provide suitable habitat for fish at different times of their life; however further research on movement tracking is needed to confirm this.

Black bream are a species of interest in the area as they have very specific nesting grounds and are targeted by recreational fishers, so understanding changes in distribution of juveniles is important in the conservation of the species (Collins and Mallinson 2012; Pinder et al. 2017). Black bream were seen to use both natural and artificial habitats as areas of refuge in their juvenile stages so conservation measures should take both habitat types into consideration.

\section{Connectivity}

Information on fine scale movement between sites for multiple marine species is lacking (Block et al. 2011), which makes conservation difficult. It is important to identify stepping stones or pathways of movement between habitats particularly between juvenile and adult habitats (Gillanders et al. 2003). This study has shown that both the natural and artificial sites are used by mobile fauna and that juveniles appear to use different sites throughout the year. The presence of subtidal artificial structures may improve the resilience of a region by providing additional habitat that could be available to different life history stages. In some regions this could create more robust metapopulations less susceptible to population losses and anthropogenic impacts. To obtain more accurate data on the connectivity between habitat patches, other techniques could be used, such as telemetry and eDNA (Gillanders et al. 2003; Lowe et al. 2003; Espinoza et al. 2011; Thomsen et al. 2012) and hydrodynamic dispersal modelling (James et al. 2002; Campbell et al. 2011).

\section{Conclusion}

Spatial and monthly variation in abundance and assemblage structure of fish and large mobile invertebrates (crustaceans and molluscs) were observed across different natural and artificial coastal sites, but there was no association with habitat type. Sampling site and month were found to influence assemblage structure with particular species showing preference for certain sites, most likely due to habitat complexity, depth and connectivity to adjacent sites. The smallest fish were typically recorded on artificial sites and the largest on natural sites, suggesting that either the fish transition between sites and habitats throughout the year, or that there is a higher rate of juvenile mortality on the artificial sites. BRUV and Stereo BRUV was a useful non-destructive tool to obtain data on the spatial and temporal variation in mobile marine assemblages; however long-term monitoring is required to obtain a more accurate understanding. The artificial habitats in this region appeared to be providing useful resources for mobile fauna. However, the construction, design and spacing of new artificial structures need to take into account the potential effects on adjacent habitats and connectivity. The findings of this study will be useful for both management of the region and also in the design and construction of future subtidal artificial structures.

Acknowledgements This study was funded by Interreg Atlantic area project 3DPARE (EAPA_174/2016). We thank numerous field assistants for help with data collection. Thank you to Poole Harbour Commissioners for permission to survey within Poole Bay. We thank the reviewers for their useful revisions.

Author contributions $\mathrm{AH}, \mathrm{RH}$ and RS contributed to the concept and design of the study. AH conducted the data collection and AH and RS ran the statistical analysis. AH wrote the main sections of the manuscript with input from RH and RS. All authors approved the submitted version.

Funding This research was funded by Interreg Atlantic area project 3DPARE (EAPA_174/2016).

Data availability The datasets generated during and/or analysed during the current study are available from the corresponding author on reasonable request.

\section{Compliance with ethical standards}

Conflicts of interest There are no conflicts of interest in this research.

Ethical approval All applicable international, national and/or institutional guidelines for sampling, care and experimental use of organisms for the study were followed, and all necessary permissions and approvals were obtained in respect of the original collections of the data.

Open Access This article is licensed under a Creative Commons Attribution 4.0 International License, which permits use, sharing, adaptation, distribution and reproduction in any medium or format, as long as you give appropriate credit to the original author(s) and the source, provide a link to the Creative Commons licence, and indicate if changes were made. The images or other third party material in this article are included in the article's Creative Commons licence, unless indicated otherwise in a credit line to the material. If material is not included in the article's Creative Commons licence and your intended use is not permitted by statutory regulation or exceeds the permitted use, you will need to obtain permission directly from the copyright holder. To view a copy of this licence, visit http://creativecommons.org/licenses/by/4.0/. 


\section{References}

Aguilera MA (2018) Artificial defences in coastal marine ecosystems in Chile: Opportunities for spatial planning to mitigate habitat loss and alteration of the marine community structure. Ecol Eng 120:601-610. https://doi.org/10.1016/j.ecoleng.2017.04.021

Airoldi L, Beck M (2007) Loss, status and trends for coastal marine habitats of Europe. In: Gibson R, Gordon J (eds) Oceanography and marine biology: an annual review. Taylor \& Francis, England, pp 345-405

Ambrose R, Swarbrick S (1989) Comparison of fish assemblages on artificial and natural reefs off the coast of southern California. Bull Mar Sci 44:718-733

Anderson MJ (2001) A new method for non-parametric multivariate analysis of variance. Austral Ecol 26:32-46. https://doi.org/10.1 046/j.1442-9993.2001.01070.x

Anderson MJ, Millar RB (2004) Spatial variation and effects of habitat on temperate reef fish assemblages in northeastern New Zealand. J Exp Mar Biol Ecol 305:191-221. https://doi.org/10.1016/j.jembe .2003 .12 .011

Anderson M, Willis T (2003) Canonical analysis of principal coordinates : a useful method of constrained ordination for ecology. Ecology 84:511-525

Bacheler NM, Shertzer KW (2015) Estimating relative abundance and species richness from video surveys of reef fishes. Fish Bull 113:15-26. https://doi.org/10.7755/FB.113.1.2

Beck MW, Heck JRK, Able K, Childers D, Eggleston D, Gillanders B, Halpern B, Hays C, Kaho H, Minello T, Orth R, Sheridan P, Weinstein M (2001) The identification, conservation, and management of estuarine and marine nurseries for fish and invertebrates. Bioscience 8:633-641

Baine M (2001) Artificial reefs: a review of their design, application, management and performance. Ocean Coast Manag 44:241-259. https://doi.org/10.1016/S0964-5691(01)00048-5

Bender A, Langhamer O, Sundberg J (2020) Colonisation of wave power foundations by mobile mega- and macrofauna - a 12 year study. Mar Environ Res 161:105053. https://doi.org/10.1016/j. marenvres.2020.105053

Bishop MJ, Mayer-Pinto M, Airoldi L, Firth LB, Morris RL, Loke LHL, Hawkins SJ, Naylor LA, Coleman RA, Chee SY, Dafforn KA (2017) Effects of ocean sprawl on ecological connectivity: impacts and solutions. J Exp Mar Biol Ecol 492:7-30. https://doi. org/10.1016/j.jembe.2017.01.021

Block BA, Jonsen ID, Jorgensen SJ, Winship AJ, Shaffer SA, Bograd SJ, Hazen EL, Foley DG, Breed GA, Harrison AL, Ganong JE, Swithenbank A, Castleton M, Dewar H, Mate BR, Shillinger GL, Schaefer KM, Benson SR, Weise MJ, Henry RW, Costa DP (2011) Tracking apex marine predator movements in a dynamic ocean. Nature 475:86-90. https://doi.org/10.1038/nature10082

Bohnsack JA (1989) Are high densities of fishes at artificial reefs the results of habitat limitation or behavioural preference? Bull Mar Sci 44:631-645

Bohnsack JA, Sutherland DLD (1985) Artificial reef research: a review with recommendations for future priorities. Bull Mar Sci 37:11-39

Bohnsack JA, Harper DE, Mcclellan DB, Hulsbeck M (1994) Effects of reef size on colonization and assemblage structure of fishes at artificial reefs off southeastern Florida, USA. Bull Mar Sci 55(28):796-823. https://www.ingentaconnect.com/content/umrsm as/bullmar/1994/00000055/f0020002/art00042

Brook FJ (2002) Biogeography of near-shore reef fishes in northern New Zealand. J R Soc N Z 32:243-274. https://doi. org/10.1080/03014223.2002.9517694

Burt J, Bartholomew A, Usseglio P, Bauman A, Sale PF (2009) Are artificial reefs surrogates of natural habitats for corals and fish in
Dubai, United Arab Emirates? Coral Reefs 28:663-675. https:// doi.org/10.1007/s00338-009-0500-1

Campbell MD, Rose K, Boswell K, Cowan J (2011) Individual-based modeling of an artificial reef fish community: effects of habitat quantity and degree of refuge. Ecol Model 222:3895-3909. https ://doi.org/10.1016/j.ecolmodel.2011.10.009

Campbell MD, Pollack AG, Gledhill CT, Switzer TS, DeVries DA (2015) Comparison of relative abundance indices calculated from two methods of generating video count data. Fish Res 170:125133. https://doi.org/10.1016/j.fishres.2015.05.011

Cappo M, Speare P, De'Ath G (2004) Comparison of baited remote underwater video stations (BRUVS) and prawn (shrimp) trawls for assessments of fish biodiversity in inter-reefal areas of the Great Barrier Reef Marine Park. J Exp Mar Biol Ecol 302:123-152. https://doi.org/10.1016/j.jembe.2003.10.006

Carr M, Hixon M (1997) Artificial reefs: the importance of comparisons with natural reefs. Fisheries 22:28-33. https://afspubs.onlin elibrary.wiley.com/doi/10.1577/1548-8446\%281997\%29022 \%3C0028\%3AARTIOC\%3E2.0.CO\%3B2

Claisse JT, Pondella DJ, Love M, Zahn LA, Williams CM, Williams JP, Bull AS (2014) Oil platforms off California are among the most productive marine fish habitats globally. Proc Natl Acad Sci USA 111:15462-15467. https://doi.org/10.1073/pnas.1411477111

Claisse JT, Pondella DJ, Love M, Zahn LA, Williams CM, Bull AS (2015) Impacts from partial removal of decommissioned oil and gas platforms on fish biomass and production on the remaining platform structure and surrounding Shell mounds. PLoS ONE 10:1-19. https://doi.org/10.1371/journal.pone.0135812

Collins KJ, Mallinson JJ (2012) Surveying black bream, Spondyliosoma cantharus (L.), nesting sites using sidescan sonar. Underw Technol 30:183-188. https://doi.org/10.3723/ut.30.183

Collins KJ, Jensen AC, Lockwood APM (1990) Fishery enhancement reef building exercise. Chem Ecol 4:179-187. https://doi. org/10.1080/02757549008035232

Connell JH, Statyer RO (1977) Mechanisms of succession in natural communities and their role in community stability and organization. Am Nat 111:1119-1144. https://doi.org/10.2307/2678832

Crawley M (2012) The R book, 2nd edn. Wiley, Sussex

Dalpadado P, Bogstad B, Eriksen E, Rey L (2009) Distribution and diet of 0-group cod (gadus morhua) and haddock (melanogrammus aeglefinus) in the Barents Sea in relation to food availability and temperature. Polar Biol 32:1583-1596. https://doi.org/10.1007/ s00300-009-0657-7

Davis TR, Smith SDA (2017) Proximity effects of natural and artificial reef walls on fish assemblages. Reg Stud Mar Sci 9:17-23. https ://doi.org/10.1016/j.rsma.2016.10.007

Dorman SR, Harvey ES, Newman SJ (2012) Bait effects in sampling coral reef fish assemblages with stereo-BRUVs. PLoS ONE 7:112. https://doi.org/10.1371/journal.pone.0041538

Dufour V, Cantou M, Lecomte F (2009) Identification of sea bass (Dicentrarchus labrax) nursery areas in the north-western Mediterranean Sea. J Mar Biol Assoc UK 89:1367-1374. https://doi. org/10.1017/S0025315409000368

Dunlop KM, Kuhnz LA, Ruhl HA, Huffard CL, Caress DW, Henthorn RG, Hobson BW, McGill P, Smith KL (2015) An evaluation of deep-sea benthic megafauna length measurements obtained with laser and stereo camera methods. Deep Sea Res Part I Oceanogr Res Papers 96:38-48. https://doi.org/10.1016/j.dsr.2014.11.003

Dunn MR (2001) The biology and exploitation of John dory, Zeus faber (Linnaeus, 1758) in the waters of England and Wales. ICES J Mar Sci 58:96-105. https://doi.org/10.1006/jmsc.2000.0993

Elliott SAM, Milligan RJ, Heath MR, Turrell WR, Bailey DM (2016) Disentangling habitat concepts for demersal marine fish management. In: Oceanography and marine biology: an annual review. pp 173-191 
Elliott SAM, Sabatino AD, Heath MR, Turrell WR, Bailey DM (2017) Landscape effects on demersal fish revealed by field observations and predictive seabed modelling. PLoS ONE 12:1-13. https://doi. org/10.1371/journal.pone.0189011

Espinoza M, Farrugia TJ, Webber DM, Smith F, Lowe CG (2011) Testing a new acoustic telemetry technique to quantify long-term, fine-scale movements of aquatic animals. Fish Res 108:364-371. https://doi.org/10.1016/j.fishres.2011.01.011

Folpp H, Lowry M, Gregson M, Suthers IM (2013) Fish assemblages on estuarine artificial reefs: natural rocky-reef mimics or discrete assemblages? PLoS ONE 8:e63505. https://doi.org/10.1371/journ al.pone. 0063505

Folpp HR, Schilling HT, Clark GF, Lowry MB, Maslen B, Gregson M, Suthers IM (2020) Artificial reefs increase fish abundance in habitat-limited estuaries. J Appl Ecol 57:1752-1761. https://doi. org/10.1111/1365-2664.13666

Froese R, Pauly D (2019) FishBase. In: World Wide Web electronic publication. www.fishbase.org

Gillanders BM, Able KW, Brown JA, Eggleston DB, Sheridan PF (2003) Evidence of connectivity between juvenile and adult habitats for mobile marine fauna: an important component of nurseries. Mar Ecol Prog Ser 247:281-295. https://doi.org/10.3354/ meps 247281

Glarou M, Zrust M, Svendsen JC (2020) Using artificial-reef knowledge to enhance the ecological function of offshore wind turbine foundations: implications for fish abundance and diversity. J Mar Sci Eng 8:332. https://doi.org/10.3390/jmse8050332

Griffin RA, Robinson GJ, West A, Gloyne-Phillips IT, Unsworth RKF (2016) Assessing fish and motile fauna around offshore windfarms using stereo baited video. PLoS ONE 11:1-14. https://doi. org/10.1371/journal.pone.0149701

Hackradt CW, Félix-Hackradt FC, García-Charton JA (2011) Influence of habitat structure on fish assemblage of an artificial reef in southern Brazil. Mar Environ Res 72:235-247. https://doi. org/10.1016/j.marenvres.2011.09.006

Haggitt T, Freeman D, Lily C (2014) Baited Remote Underwater Video Guidelines. New Zealand

Hale R, Swearer SE (2016) Ecological traps: current evidence and future directions. Proc R Soc B Biol Sci 283:1-8. https://doi. org/10.1098/rspb.2015.2647

Hall AE (2018) The ecology and ecological enhancement of artificial coastal structures. Bournemouth University, PhD Thesis. http:// eprints.bournemouth.ac.uk/30570/

Harrison XA, Donaldson L, Correa-Cano ME, Evans J, Fisher DN, Goodwin CED, Robinson BS, Hodgson DJ, Inger R (2018) A brief introduction to mixed effects modelling and multi-model inference in ecology. PeerJ 2018:1-32. https://doi.org/10.7717/peerj.4794

Harvey ES, Cappo M, Butler JJ, Hall N, Kendrick GA (2007) Bait attraction affects the performance of remote underwater video stations in assessment ofdemersal fish community structure. Mar Ecol Prog Ser 350:245-254. https://doi.org/10.3354/meps07192

Harvey ES, Shortis MR (1998) Calibration stability of an underwater stereo-video system: implications for measurement accuracy and precision. Mar Technol Soc J 32:3-17

Herbert RJ, Collins K, Mallinson J, Hall AE, Pegg J, Ross K, Clarke L, Clements T (2017) Epibenthic and mobile species colonisation of a geotextile Artificial Surf Reef on the south coast of England. PLoS ONE 12:1-28. https://doi.org/10.1371/journal.pone.01841 00

Hiscock K, Southward A, Tittley IAN, Hawkins S (2004) Effects of changing temperature on benthic marine life in Britain and Ireland. Aquat Conserv Mar Freshw Ecosyst 14:333-362. https:// doi.org/10.1002/aqc.628
Hixon M, Beets J (1989) Shelter characteristics and Caribbean fish assemblages: experiments with artificial reefs. Bull Mar Sci 44:666-680

Humphries NE, Simpson SJ, Wearmouth VJ, Sims DW (2016) Two's company, three's a crowd: fine-scale habitat partitioning by depth among sympatric species of marine mesopredator. Mar Ecol Prog Ser 561:173-187. https://doi.org/10.3354/meps11937

Hunter WR, Sayer MDJ (2009) The comparative effects of habitat complexity on faunal assemblages of northern temperate artificial and natural reefs. ICES J Mar Sci 66:691-698. https://doi.org/10.1093/ icesjms/fsp058

SIFCA (2020) Southern Inshore Fisheries and Conservation Authority. southern-ifca.gov.uk/district-fisheries

James MK, Armsworth PR, Mason LB, Bode L (2002) The structure of reef fish metapopulations: modelling larval dispersal and retention patterns. Proc Biol Sci/R Soc 269:2079-2086. https://doi. org/10.1098/rspb.2002.2128

Jennings S, Kaiser M, Reynolds J (2001) Marine fisheries ecology. Blackwell Publishing, Hoboken

Jensen A, K C, Smith P (2000) The Poole Bay Artificial Reef Project. In: Artificial Reefs in European Seas. Kluwer Academic Publishers, pp 263-287

Johnson DW (2006) Predation, habitat complexity, and variation in density-dependent mortality of temperate reef fishes. Ecology 87:1179-1188. https://doi.org/10.1890/00129658(2006)87[1179:PHCAVI]2.0.CO;2

Komyakova V, Swearer SE (2019) Contrasting patterns in habitat selection and recruitment of temperate reef fishes among natural and artificial reefs. Mar Environ Res 143:71-81. https://doi. org/10.1016/j.marenvres.2018.11.005

Kopp D, Le Bris H, Grimaud L, Nérot C, Brind'Amour A (2013) Spatial analysis of the trophic interactions between two juvenile fish species and their preys along a coastal-estuarine gradient. J Sea Res 81:40-48. https://doi.org/10.1016/j.seares.2013.03.013

Krone R, Gutow L, Brey T, Dannheim J, Schröder A (2013) Mobile demersal megafauna at artificial structures in the German Bightlikely effects of offshore wind farm development. Estuar Coast Shelf Sci 125:1-9. https://doi.org/10.1016/j.ecss.2013.03.012

Langhamer O, Holand H, Rosenqvist G (2016) Effects of an Offshore Wind Farm (OWF) on the common shore crab carcinus maenas: tagging pilot experiments in the Lillgrund Offshore Wind Farm (Sweden). PLoS ONE 11:1-17. https://doi.org/10.1371/journ al.pone. 0165096

Loke LHL, Ladle RJ, Bouma TJ, Todd PA (2015) Creating complex habitats for restoration and reconciliation. Ecol Eng 77:307-313. https://doi.org/10.1016/j.ecoleng.2015.01.037

Lowe CG, Topping DT, Cartamil DP, Papastamatiou YP (2003) Movement patterns, home range, and habitat utilization of adult kelp bass Paralabrax clathratus in a temperate no-take marine reserve. Mar Ecol Prog Ser 256:205-216. https://doi.org/10.3354/meps2 56205

Malcolm HA, Gladstone W, Lindfield S, Wraith J, Lynch TP (2007) Spatial and temporal variation in reef fish assemblages of marine parks in New South Wales, Australia-Baited video observations. Mar Ecol Prog Ser 350:277-290. https://doi.org/10.3354/meps0 7195

Mallinson J, Collins K, Jensen A (1999) Species recorded on artificial and natural reefs, Poole Bay. In: Proceedings of the Dorset Natural Hostory andArchaeological Society. pp 113-122

Messmer V, Jones GP, Munday PL, Holbrook SJ, Schmitt RJ, Brooks AJ (2011) Habitat biodiversity as a determinant of fish community structure on coral reefs. Ecology 92:2285-2298. https://doi. org/10.1890/11-0037.1

Moland E, Olsen EM, Knutsen H, Knutsen JA, Enersen SE, André C, Stenseth NC (2011) Activity patterns of wild European lobster 
Homarus gammarus in coastal marine reserves: implications for future reserve design. Mar Ecol Prog Ser 429:197-207. https:// doi.org/10.3354/meps09102

Nanami A, Nishihira M (2003) Population dynamics and spatial distribution of coral reef fishes. Environ Biol Fishes 68:101-112

Pastor J, Koeck B, Astruch P, Lenfant P (2013) Coastal man-made habitats: potential nurseries for an exploited fish species, Diplodus sargus (Linnaeus, 1758). Fish Res 148:74-80. https://doi. org/10.1016/j.fishres.2013.08.014

Paxton AB, Shertzer KW, Bacheler NM, Kellison GT, Riley KL, Taylor JC (2020) Meta-analysis reveals artificial reefs can be effective tools for fish community enhancement but are not one-size-fits-all. Front Mar Sci. https://doi.org/10.3389/fmars.2020.00282

Perry AL, Low PJ, Ellis JR, Reynolds JD (2005) Climate change and distribution shifts in marine fishes. Science 308:1912-1915. https ://doi.org/10.1126/science.1111322

Pickering H, Whitmarsh D (1997) Artificial reefs and fisheries exploitation: a review of the 'attraction versus production' debate, the influence of design and its significance for policy. Fish Res 31:39 59. https://doi.org/10.1016/S0165-7836(97)00019-2

Pinder AC, Velterop R, Cooke SJ, Britton JR (2017) Consequences of catch-and-release angling for black bream Spondyliosoma cantharus, during the parental care period: implications for management. ICES J Mar Sci 74:254-262. https://doi.org/10.1093/icesj $\mathrm{ms} / \mathrm{fsw} 151$

Ponti M, Fava F, Perlini RA, Giovanardi O, Abbiati M (2015) Benthic assemblages on artificial reefs in the northwestern Adriatic Sea: does structure type and age matter? Mar Environ Res 104:10-19. https://doi.org/10.1016/j.marenvres.2014.12.004

Randall J (1963) An analysis of the fish populations of artificial and natural reefs in the Virgin Islands. Carib J Sci 3:31-47

Reubens JT, Braeckman U, Vanaverbeke J, Van Colen C, Degraer S, Vincx M (2013) Aggregation at windmill artificial reefs: CPUE of Atlantic cod (Gadus morhua) and pouting (Trisopterus luscus) at different habitats in the Belgian part of the North Sea. Fish Res 139:28-34. https://doi.org/10.1016/j.fishres.2012.10.011

Reubens JT, De Rijcke M, Degraer S, Vincx M (2014) Diel variation in feeding and movement patterns of juvenile Atlantic cod at offshore wind farms. J Sea Res 85:214-221. https://doi.org/10.1016/j.seare s.2013.05.005

Sanders RM, Chandler CR, Landry AM (1985) Hydrological, diel and lunar factors affecting fishes on artificial reefs off Panama City, Florida. Bull Mar Sci 37:318-328

Schlaepfer MA, Runge MC, Sherman PW (2002) Ecological and evolutionary traps. Trends Ecol Evol 17:474-480. https://doi. org/10.1016/S0169-5347(02)02580-6

Schmid K, Reis-Filho JA, Harvey E, Giarrizzo T (2017) Baited remote underwater video as a promising nondestructive tool to assess fish assemblages in clearwater Amazonian rivers: testing the effect of bait and habitat type. Hydrobiologia 784:93-109. https://doi. org/10.1007/s10750-016-2860-1

Schramm KD, Harvey ES, Goetze JS, Travers MJ, Warnock B, Saunders BJ (2020) A comparison of stereo-BRUV, diver operated and remote stereo-video transects for assessing reef fish assemblages. J Exp Mar Biol Ecol 524:151273. https://doi.org/10.1016/j.jembe .2019 .151273

Schultz AL, Malcolm HA, Bucher DJ, Smith SDA (2012) Effects of reef proximity on the structure of fish assemblages of unconsolidated substrata. PLoS ONE. https://doi.org/10.1371/ journal.pone.0049437

SeaGIS Ply Ltd (2019) EventMeasure.

SeaGIS Ply Ltd (2020) SeaGIS. https://www.seagis.com.au/hardware. html

Seitz RD, Bergstro U, Lipcius RN, Ysebaert T (2014) Ecological value of coastal habitats for commercially and ecologically important species. ICES J Mar Sci 71:648-665

Sheehan EV, Cartwright AY, Witt MJ, Attrill MJ, Vural M, Holmes LA (2020) Development of epibenthic assemblages on artificial habitat associated with marine renewable infrastructure. ICES J Mar Sci 77:1178-1189. https://doi.org/10.1093/icesjms/fsy151

Stål J, Paulsen S, Pihl L, Rönnbäck P, Söderqvist T, Wennhage H (2008) Coastal habitat support to fish and fisheries in Sweden: integrating ecosystem functions into fisheries management. Ocean Coast Manag 51:594-600. https://doi.org/10.1016/j.oceco aman.2008.06.006

Stoner AW (2004) Effects of environmental variables on fish feeding ecology: implications for the performance of baited fishing gear and stock assessment. J Fish Biol 65:1445-1471. https://doi.org/ 10.1111/j.1095-8649.2004.00593.x

Temming A, Götz S, Mergardt N, Ehrich S (2004) Predation of whiting and haddock on sandeel: aggregative response, competition and diel periodicity. J Fish Biol 64:1351-1372. https://doi.org/10.11 11/j.0022-1112.2004.00400.x

Thomsen PF, Kielgast J, Iversen LL, Møller PR, Rasmussen M, Willerslev E (2012) Detection of a diverse marine fish fauna using environmental DNA from seawater samples. PLoS ONE 7:1-9. https://doi.org/10.1371/journal.pone.0041732

Unsworth RKF, Peters JR, McCloskey RM, Hinder SL (2014) Optimising stereo baited underwater video for sampling fish and invertebrates in temperate coastal habitats. Estuar Coast Shelf Sci 150:281-287. https://doi.org/10.1016/j.ecss.2014.03.020

Vega Fernández T, D’Anna G, Badalamenti F, Pérez-Ruzafa A (2008) Habitat connectivity as a factor affecting fish assemblages in temperate reefs.Aquat Biol 1:239-248. https://doi.org/10.3354/ ab00027

Wearmouth VJ, Southall EJ, Morritt D, Sims DW (2013) Identifying reproductive events using archival tags: egg-laying behaviour of the small spotted catshark Scyliorhinus canicula. J Fish Biol 82:96-110. https://doi.org/10.1111/j.1095-8649.2012.03473.x

Whitmarsh SK, Fairweather PG, Huveneers C (2017) What is Big BRUVver up to? Methods and uses of baited underwater video. Rev Fish Biol Fish 27:53-73. https://doi.org/10.1007/s1116 0-016-9450-1

Wilhelmsson D, Malm T, Öhman MC (2006) The influence of offshore windpower on demersal fish. ICES J Mar Sci 63:775-784. https:// doi.org/10.1016/j.icesjms.2006.02.001

Zheng X, Pierce GJ, Reid DG, Jolliffe IT (2002) Does the North Atlantic current affect spatial distribution of whiting? Testing environmental hypotheses using statistical and GIS techniques. ICES J Mar Sci 59:239-253. https://doi.org/10.1006/jmsc.2001.1131

Publisher's Note Springer Nature remains neutral with regard to jurisdictional claims in published maps and institutional affiliations. 